\title{
Aspecte terapeutice moderne în două cazuri de hiperinsulinism congenital
}

\author{
Cristian Minulescu ${ }^{1,2}$, Dana Spirea ${ }^{3,4}$ \\ ${ }^{1}$ Dr. Cristian Minulescu PFA, MedLife, Bucureşti, România \\ ${ }^{2}$ Société Francaise pour l'Etude des Maladies Héréditaires du Métabolisme, France \\ ${ }^{3}$ Spitalul Clinic pentru Copii, Braşov, România \\ ${ }^{4}$ The European Society for Paediatric Gastroenterology Hepatology and Nutrition
}

\begin{abstract}
REZUMAT
În articolul de faţă vom prezenta aspectele terapeutice şi clinice regăsite în cazul a doi pacienţi de vârstă pediatrică diagnosticaţi cu hiperinsulinism congenital. Astfel, dorim să arătăm principiile terapeutice moderne folosite în tratarea acestor pacienţi. Este important de reţinut că hiperinsulinismul congenital este singura boală congenitală de metabolism curabilă, terapia chirurgicală nemaifiind indicată astăzi decât în cazuri izolate.

De aceea, este important ca diagnosticul să fie pus rapid, întrucât hipoglicemiile din această boală sunt severe. De asemenea, hiperinsulinismul congenital blochează cetogeneza, astfel că nici creierul şi nici miocardul nu mai pot folosi corpii cetonici ca substrat energetic alternativ în cazul unei hipoglicemii, riscul apariţiei leziunilor cerebrale sau a stopului cardiac fiind foarte mare în această boală.
\end{abstract}

Cuvinte cheie: hipoglicermie hipocetotică, boală curabilă, diazoxid

\section{INTRODUCERE}

Pancreasul este un organ cu rol atât exocrin, cât şi endocrin. Cel mai important hormon secretat de acesta este insulina. Rolurile acestuia sunt multiple, dar cel mai important este acela de a scădea nivelul glicemiei (1). Această capacitate de tamponare a glucozei este însă limitată, pancreasul având capacitatea de a secreta insulină suficientă pentru a tampona un debit de glucoză de maximum $10 \mathrm{mg} / \mathrm{kg} / \mathrm{min}$, o cantitate mai mare de glucoză depăşind capacitatea acestuia de a secreta insulină şi provocând hiperglicemie.

Un alt rol al insulinei este cel anabolizant, favorizând sinteza proteică (2). Acest rol este unul extrem de important în cazul pacienţilor cu boli congenitale de metabolism atât pentru terapia acestor boli, cât şi pentru înţelegerea fiziopatologiei acestora.

Scăderea producţiei de insulină duce la diabet zaharat, iar creşterea acestei producţii determină o tulburare numită hiperinsulinism congenital. Aceasta are trei forme principale, una focală, una difuză şi alta numită sindromică (3).
Forma cel mai des întâlnită este cea focală, în această situaţie existând o hiperproliferare izolată a celulelor pancreatice, ceea ce duce la apariţia unui insulinom.

In forma difuză, această hiperproliferare cuprinde întregul pancreas, iar în cea sindromică hiperinsulinismul apare în contextul unui sindrom genetic, care are şi alte manifestări pe lângă anomalia pancreatică (4).

\section{METODĂ}

În lucrarea de faţă vom prezenta cazurile a doi pacienţi diagnosticaţi şi trataţi de către autori pentru hiperinsulinism congenital. Diagnosticul a fost stabilit prin calcularea debitului de glucoză necesar controlării hipoglicemiei şi prin testul la glucagon. Rolul testării genetice rămâne mic în această patologie, dar testări genice au fost efectuate la ambii pacienţi. 


\section{PREZENTAREA CAZURILOR}

\section{Cazul 1}

Este cel al unui sugar de 5 luni, de sex feminin, care s-a născut din părinţi consanguini de grad mare. Începând cu vârsta de 2-3 zile, prezintă o stare generală alterată şi tremor fin al extremităţilor membrelor inferioare, în contextul unei glicemii de $27 \mathrm{mg} / \mathrm{dl}$. Astfel, se iniţiază terapie cu glucoză iv în ritm de $6 \mathrm{mg} / \mathrm{kg} / \mathrm{min}$, crescută progresiv la $8 \mathrm{mg} / \mathrm{kg} / \mathrm{min}$. Se interpretează ca sepsis neonatal şi se inţiază antibioterapie empirică cu supravegherea glicemiilor. Sub acest tratament, prezintă crize tonicoclonice generalizate în prezenţa unei glicemii de $4 \mathrm{mg} / \mathrm{dl}$.

În spitalul Braşov, pacienta este spitalizată pe o perioadă de 3 zile, timp în care nu repetă manifestările neurologice, însă starea generală se menţine mediocră, cu glicemii cu valori între 24 şi $50 \mathrm{mg} / \mathrm{dl}$ care au necesitat ritm continuu de glucoză $9-11 \mathrm{mg} / \mathrm{kg} / \mathrm{min}$. $\mathrm{Au}$ fost excluse hipoglicemia tranzitorie asociată diabetului gestaţional şi sepsisul neonatal.

Pe parcursul acestei spitalizări, se continuă investigaţiile de laborator cu reevaluare profil septic, care evidenţiază Klebsiella pn. în secreţia ombilicală şi astfel se iniţiază tratament conform antibiogramei. Persistă hipoglicemia în ciuda tratamentului, motiv pentru care se suplimentează alimentaţia cu glucoză pulvis la fiecare biberon şi bolusuri repetate de glucoză $10 \%$ iv. Întrucât celelalte cauze de hipoglicemie severă a nou-născutului au fost eliminate, se ia în considerare o afecţiune endocrinologică pentru care se recoltează ACTH, cortizol seric, STH, hormoni tiroidieni, insulină şi peptidul $\mathrm{C}$, toate cu valori normale. De asemenea, explorările imagistice efectuate (ecografie abdominală şi transfontanelară) au fost normale. La investigaţiile serologice, se evidenţiază hiperamoniemie şi acid lactic peste valorile normale, asociată unui discret sindrom de hepatocitoliză. Ţinând cont de aceste modificări, se ridică suspiciunea unei boli de stocare a glicogenului, hepatomegalia putând lipsi la vârsta neonatală. Se recoltează probe genetice pentru confirmarea acestui diagnostic şi se externează cu recomandări de suplimentare a aportului oral de glucoză prin adăugare la fiecare biberon de Polycal (maltodextrină) şi Kreon la fiecare masă, iar pentru corectarea eventualelor hipoglicemii se va administra glucoză $10 \%$ oral.

Panelul genetic care testează cele 23 gene cunoscute ce pot determina apariţia glicogenozei are rezultat negativ pentru fiecare genă. Hipoglicemiile au persistat, iar pentru asigurarea normoglicemiei s-a folosit un debit de glucoză de peste $10 \mathrm{mg} / \mathrm{kg} / \mathrm{min}$. În acest moment, se ridică suspiciunea de hiperinsulinism congenital şi se efectuează un test cu glucagon, care a fost pozitiv. Un tratament iniţial cu octreotid a fost început. Sub acesta, s-a obţinut o ameliorare a glicemiilor, dar nu o normalizare a lor. Din acest motiv, a fost necesar ca laptele pe care îl primea pacienta să fie îmbogăţit nu doar cu dextrinmaltoză, ci şi cu glucoză, pentru a se asigura un aport crescut de glucoză. Întrucât sugarul nu se alimenta corespunzător, s-a folosit un gavaj continuu iniţial, apoi discontinuu. Ulterior, s-au folosit o pompă de nutriţie şi un buton de gastrostomă. Pacienta a fost externată cu acest tratament. O testare genetică a fost realizată folosindu-se un panel ce cuprindea toate genele cunoscute până în acest moment ca fiind implicate în patogenia hiperinsulinismului, acestea fiind secvenţiate prin tehnica NGS. Rezultatul a fost însă negativ.

După câteva luni, păstrarea glicemiilor corecte a devenit din ce în ce mai dificilă, iar debitul de glucoză a trebuit crescut şi mai mult. În această situaţie, s-a înlocuit octreotidul cu diazoxid, ceea ce a dus la o normalizare a rapidă a profilului glicemic. Nutriţia orală a fost reluată la scurt timp, ceea ce a permis suprimarea gastrostomei. Rare hipoglicemii au mai fost înregistrate în lunile următoare, dar au dispărut ulterior.

\section{Cazul 2}

Este cel al unei fetiţe de trei ani care a avut mai multe episoade de hipoglicemie. Pacienta s-a născut prematur la 34 de săptămâni, adaptare postnatală fiind dificilă. Hipoglicemiile s-au manifestat încă din perioada neonatală, necesitând o terapie cu glucoză cu debit de $16 \mathrm{mg} / \mathrm{kg} / \mathrm{min}$ pentru controlul acestora. $\mathrm{Nu}$ se fac însă alte investigaţii pentru a se stabili etiologia acestora. Pe parcursul primului an de viaţă, persistă hipoglicemiile, care duc la convulsii tonico-clonice generalizate. La vârsta de 9 luni, este internată pentru convulsii în context hipoglicemic, aceste internări repetându-se din două în două luni. La vârsta de doi ani, se decelează ecografic un rinichi stâng mai mare decât cel drept, o hipertrofie a jumătăţii stângi a limbii şi un perimetru al membrului superior stâng mai mare decât al celui drept. Se ridică suspiciunea unui sindrom Beckwith-Wiedemann, dar nu sunt efectuate testele genetice şi nu este confirmat diagnosticul. La această vârstă însă, fetiţa dezvoltă o tumoră de uracă, pentru care necesită cură chirurgicală.

Diagnosticul de hiperinsulinism congenital a fost stabilit la vârsta de trei ani. Suspiciunea a fost ridicată pornind de la debitul de glucoză de peste $10 \mathrm{mg} / \mathrm{kg}$ / min necesar controlului hipoglicemiilor în perioada neonatală. Pentru confirmarea diagnosticului, am efectuat un test la glucagon, care a fost pozitiv. Clinic, 
pacienta prezenta strabism convergent şi hipertrofia jumătăţii stângi a limbii, constipaţie cronică şi incontinenţă. Nu existau semne clare de suferinţă neurologică.

Terapia a constat în îmbogăţirea alimentaţiei cu fibre şi amidon de porumb de tip Maizena, ceea ce a dus la dispariţia constipaţiei şi a hipoglicemiilor. De asemenea, s-a administrat diazoxid în doză de $10 \mathrm{mg} /$ $\mathrm{kg} / \mathrm{zi}$. Iniţial, pacientul l-a tolerat prost, având dureri abdominale şi vărsături, ulterior dezvoltând toleranţă pentru medicament. Sub această terapie, glicemiile au fost superioare valorii de $100 \mathrm{mg} / \mathrm{dl}$, ceea ce a permis oprirea amidonului de porumb.

O secvenţiere prin tehnica NGS a genei CDKN1C a fost realizată, rezultatul fiind unul negativ. Restul anomaliilor genetice implicate în patogenia sindromului Beckwith-Wiedmann nu au putut fi căutate. Având în vedere însă dismorfismele copilului, rămâne totuşi suspiciunea unui hiperinsulinism sindromic, posibil Beckwith-Wiedmann.

De asemenea, un test de toleranţă orală la glucoză a fost efectuat, acesta nedecelând anomalii de cinetică în secreţia de insulină (vezi tabelul 1).

TABEL 1. Rezultatele testului de toleranţă orală la glucoză

\begin{tabular}{|l|l|}
\hline Moment & Valoarea glicemiei \\
\hline T0 & $50 \mathrm{mg} / \mathrm{dl}$ \\
\hline T1h & $171 \mathrm{mg} / \mathrm{dl}$ \\
\hline T2h & $89 \mathrm{mg} / \mathrm{dl}$ \\
\hline
\end{tabular}

O investigaţie IRM cu substanţă de contrast efectuată identifică o formaţiune nodulară localizată la nivelul cozii pancreasului, fără priza substanţei de contrast, şi o dilatare a colonului.

\section{DISCUŢII}

Hiperinsulinismul (HI) congenital este cea mai frecventă cauză de hipoglicemie în practica pediatrică, dacă nu luăm în discuţie hipoglicemia funcţională.

Deşi tabloul clinic este impresionant şi, uneori poate avea aspecte dramatice, prognosticul bolii pe termen lung este unul bun, forma farmacosensibilă fiind singura boală congenitală de metabolism curabilă.

Terapia acestei boli a cunoscut progrese deosebite în ultimii ani, existând în momentul acesta trei preparate farmaceutice ce pot fi folosite.

Există mai multe forme de hiperinsulinism, fiecare dintre ele având anumite particularităţi în ceea ce priveşte tratamentul, dar şi prognosticul $(5,6)$.

O discuţie specială, în viziunea autorilor acestui articol, o merită testarea genetică în această boală. Deşi au fost descrise mai multe gene implicate în patogenia hiperinsulinismului congenital, la 50\% dintre aceşti pacienţi nu se descoperă o mutaţie în momentul testării. Acest fapt face foarte puţin utilă testarea genetică pentru stabilirea diagnosticului de hiperinsulinism congenital. Mult mai util rămâne testul la glucagon pentru diagnosticarea acestor pacienţi. De asemenea, foarte utilă pentru recunoaşterea rapidă a acestei boli este calcularea debitului de glucoză necesar controlării hipoglicemiilor. Dacă acest debit depăşeşte $10 \mathrm{mg} / \mathrm{kg} / \mathrm{min}$, diagnosticul este sigur, nemaifiind necesare alte teste.

De asemenea, trebuie menţionat faptul că determinarea insulinemiei nu are utilitate diagnostică reală în această boală. Această dozare se face într-o venă periferică, unde nivelul insulinemiei poate fi fals normal, aşadar, un nivel normal al insulinemiei nu exclude diagnosticul de hiperinsulinism.

Un tip particular de HI este cel sindromic. În aceste situaţii, hipoglicemia hiperinsulinemică este asociată altor manifestări legate de sindromul respectiv, ceea ce face ca tratamentul să fie mai complicat, iar abordarea devine multidisciplinară.

Prognosticul în această situaţie este mult influenţat de paricularităţile sindromului respectiv.

Terapia acestei boli are două componente mari, una medicamentoasă şi alta chirurgicală.

\section{Terapia medicamentoasă}

În prezent, terapia medicamentoasă este de primă intenţie, având în vedere că sub acţiunea medicamentelor recomandate pancreasul îşi recapătă în timp funcţia normală.

Există mai multe medicamente care se pot folosi, acestea putând fi clasificate, în viziunea autorilor acestui articol, în trei grupe mari; cele a căror eficienţă nu poate fi contestată, cele care uneori s-au dovedit eficiente, dar trebuie folosite cu prudenţă, şi cele experimentale.

În categoria celor cu eficienţă certă, introducem diazoxidul, octreotidul şi lanreotidul. Diazoxidul este considerat ca medicament de primă linie, el fiind foarte util atât în terapia formelor focale, cât şi în formele difuze. Totuşi, există forme rezistente care nu pot fi tratate cu acest medicament (6). Sunt citate ca efecte adverse hipertricoza, retenţia de fluide, trombocitopenia, neutropenia şi hiperuricemia, aceste lucruri indicând faptul că o urmărire atentă a pacienţilor aflaţi sub diazoxid este obligatorie (7).

Octreotidul este un medicament cu eficienţă dovedită, dar are câteva dezavantaje care îl fac mai puţin utilizat decât diazoxidul. Primul este calea de administrare, aceasta fiind exclusiv injectabilă, ceea ce scade complianţa terapeutică a copiilor. Al doilea este reprezentat de efectele adverse, el putând provoca 
litiază biliară şi enterocolită necrozantă. Un aspect interesant al acestui medicament este faptul că poate induce tahifilaxie, adică pierderea bruscă a eficacităţii. Mecanismul nu se cunoaşte (8).

În unele cazuri atent selectate, putem folosi nifedipina sau glucagonul. În cazul alegerii nifedipinei, totuşi, este utilă efectuarea testării genetice, întrucât ea s-a dovedit eficientă în mutaţiile genei ABCC8, dar nu şi în alte forme. Răspunsul la nifedipină este rar în această boală şi studii suplimentare sunt necesare pentru a stabili locul său în terapia HI congenital (9).

Glucagonul a fost mult timp folosit în tratamentul hiperinsulinismului congenital, în special în timpul fazei acute şi pentru combaterea hipoglicemiei. Astăzi, s-a observat că acesta dă însă fenomene de rebound, ceea ce a redus foarte mult utilizarea lui. În cazuri de urgenţă majoră însă (comă), mai ales când administrarea intrarectală nu este posibilă, el se poate folosi. De asemenea, sunt descrise efecte adverse redutabile în cazul folosirii acestuia, mai ales în cazul unei utilizări îndelungate sau al dozelor mari. Un astfel de efect este apariţia unui eritem necrotic migrator. Deşi rar, acesta poate fi extrem de greu de corectat şi se recomandă o urmărire atentă a pacientului. $\mathrm{O}$ reală preocupare este, de asemenea, creşterea riscului de tromboză în cazul tratamentului cronic cu glucagon. Deşi mecanismul nu este clar, sunt centre care recomandă adăugarea de heparină cu greutate moleculară mică atunci când se alege folosirea glucagonului ca tratament de durată (10).

Pentru combaterea hipoglicemiei, preferăm să folosim glucoză 33\% administrată intrarectal $(1 \mathrm{ml} /$ $\mathrm{kgc})$. Pentru tratamentul fazei acute, se va folosi glucoză în debit de $16-17 \mathrm{mg} / \mathrm{kg} / \mathrm{min}$ la nou-născut şi $12-13 \mathrm{mg} / \mathrm{kg} / \mathrm{min}$ la sugar.

Două medicamente experimentale reţin atenţia, exendin şi sirolimus. Acesta din urmă însă este un imunosupresor şi se recomandă prudenţă (8).

$O$ altă terapie încercată a mai fost dieta cetogenă. Eficienţa ei este discutabilă şi sunt foarte puţine cazuri raportate de HI congenital care au răspuns la această terapie (11).

\section{Terapia chirurgicală}

Intervenţia chirurgicală se adresează în special formelor focale. În formele difuze, se poate interveni chirurgical doar în cazul lipsei de răspuns la terapia medicamentoasă sau dietetică. Pentru a se stabili forma histopatologică, este necesară efectuarea unei investigaţii de tip PET-CT, celelalte tehnici imagistice nefiind indicate de rutină. Din păcate, această investigaţie nu este posibilă în România din cauza unor probleme birocratice, programul naţional de PET-CT nedecontând această investigaţie decât pentru pacienţii cu afecţiuni oncologice şi nu şi pentru bolnavii cu hiperinsulinism congenital.

Mai multe tehnici chirurgicale sunt folosite în terapia acestor pacienţi în funcţie de forma histopatologică (focală, difuză, atipică) (12).

În forma focală, se recomandă o intervenţie limitată strict la tumoră, aceasta făcându-se sub ghidaj PET-CT. Se încearcă astfel sa se conserve cât mai mult ţesut pancreatic pentru a se evita un diabet secundar. În cazul formelor focale profunde însă, este posibil ca această tehnică să nu fie posibilă, fiind necesară o rezecţie extinsă de ţesut pancreatic.

În cazul formelor difuze, rezecţia pancreatică focală nu mai este posibilă, fiind necesară o pancreatectomie totală, ceea ce va duce la un diabet secundar.

În cazul formelor atipice, nu există o tehnică standard, chirurgul trebuind să îşi adapteze intervenţia în funcţie de particularităţile cazului în aşa fel încât să poată salva cât mai mult ţesut pancreatic.

Într-un studiu publicat de o echipă de la spitalul de copii din Philadelphia (13), dintr-un total de 500 de pacienţi, 261 au avut forme focale, dintre care 15 au fost insulinoame izolate şi doar 202 forme difuze, iar 37 au fost forme atipice. Dintre pacienţii cu forme focale, $97 \%$ s-au vindecat complet după operaţie și doar 1 pacient suferă de diabet secundar. În cazul pacienţilor cu forme difuze însă, dintr-un total de 202 pacienţi operaţi, $47 \%$ au dezvoltat un diabet secundar. În cazul formelor atipice şi al insulinoamelor, rezultatele au fost, de asemenea, mulţumitoare, rata de vindecare fiind de $>95 \%$.

Un alt studiu publicat de un colectiv francez a arătat o rată de apariţie a diabetului secundar de $0 \%$ după intervenţia chirurgicală pentru formele focale, dar de $95 \%$ în cazul formelor difuze (14).

O statistică publicată de un grup din Londra a arătat o incidenţă a diabetului de $96 \%$ după intervenţia pentru formele difuze (15).

Aceste statistici indică clar importanţa terapiei medicamentoase şi descoperirea de noi molecule, în special pentru formele difuze. Testarea răspunsului la diazoxid şi octreotid este obligatorie în toate formele de HI înainte de a se recurge la terapia chirurgicală.

Rezultate încurajatoare în acest sens s-au obţinut în cazul unei molecule numite exendin. Aceasta este un antagonist al receptorilor pentru GLP-1 (glucagonlike-protein 1), care poate fi folosit pentru cazurile de HI datorat blocării activităţii canalelor de potasiu ATP-dependente. Eficienţa acestei molecule a fost evaluată în cadrul unui studiu dublu-orb randomizat placebo controlat efectuat de un colectiv din SUA (16). S-a folosit un lot de 9 pacienţi cu mutaţii în gena ABCC8 şi s-a remarcat că sub tratament cu exendin 
au dispărut complet hipoglicemiile la toţi aceşti pacienţi. Aceste rezultate sunt foarte încurajatoare, mai ales că mutaţiile în gena $\mathrm{ABCC} 8$ induc de multe ori rezistență la diazoxid, iar octreotidul poate produce la nou-născut enterocolită necrozantă (17).

Având în vedere numărul mic de pacienţi, sunt necesare noi studii legate de exendin.

\section{CONCLUZII}

Hiperinsulinismul congenital rămâne până în ziua de astăzi singura boală congenitală de metabolism curabilă. Din acest motiv, stabilirea diagnosticului la

\section{BIBLIOGRAFIE}

1. Herzog RI, Sherwin RS, Rothman DL. Insulin-induced hypoglycemia and its effect on the brain: Unraveling metabolism by in vivo nuclear magnetic resonance. Diabetes. 2011;60(7):1856-8.

2. Fujita S, Rasmussen BB, Cadenas JG, Grady JJ, Volpi E. Effect of insulin on human skeletal muscle protein synthesis is modulated by insulin-induced changes in muscle blood flow and amino acid availability. Am J Physiol Endocrinol Metab. 2006 Oct;291(4):E745-54.

3. de Lonlay P, Dubois S, Valayannopoulos V, Depondt E, Ottolenghi C, Rabier D. Déficit de l'oxydation des acides gras. In Prise en charge médicale et diététique des maladies héréditaires du métabolisme. Paris: Springer, 2013, p. 307.

4. Arnoux JB, Verkarre V, Saint-Martin C, Montravers F, Brassier A, Valayannopoulos V, Brunelle F, Fournet JC, Robert JJ, Aigrain Y, Bellanné-Chantelot $\mathrm{C}$, de Lonlay $\mathrm{P}$. Congenital hyperinsulinism: Current trends in diagnosis and therapy. Orphanet J Rare Dis. 2011;6:63.

5. Demirbilek H, Hussain K. Congenital Hyperinsulinism: Diagnosis and Treatment Update. J Clin Res Pediatr Endocrinol. 2017; 9(Suppl 2):69-87.

6. Henquin JC, Nenquin M, Sempoux C, Guiot Y, Bellanné-Chantelot C, Otonkoski T, de Lonlay $\mathrm{P}$, Nihoul-Fékété $\mathrm{C}$, Rahier J. In vitro insulin secretion by pancreatic tissue from infants with diazoxide-resistant congenital hyperinsulinism deviates from model predictions. J Clin Invest. 2011;121(10):3932-42.

7. Herrera A, Vajravelu ME, Givler S, Mitteer L, Avitabile CM, Lord K, De León DD. Prevalence of Adverse Events in Children With Congenital Hyperinsulinism Treated With Diazoxide. J Clin Endocrinol Metab. 2018;103(12):4365-4372.

8. Banerjee I, Salomon-Estebanez M, Shah P, Nicholson J, Cosgrove KE, Dunne MJ. Therapies and outcomes of congenital hyperinsulinisminduced hypoglycaemia. Diabet Med. 2019;36(1):9-21.

9. Khawash P, Hussain K, Flanagan SE, Chatterjee S, Basak D. Nifedipine in Congenital Hyperinsulinism - A Case Report. J Clin Res Pediatr Endocrinol. 2015;7(2):151-4. timp, înaintea apariţiei leziunilor cerebrale secundare hipoglicemiei, şi iniţierea rapidă a tratamentului corect sunt esențiale pentru păstrarea unui prognostic bun.

Intervenţia chirurgicală trebuie amânată cât mai mult timp, pâna la evaluarea răspunsului la tratamentul medicamentos, mai ales pentru formele difuze, iar atunci când se recurge la ea este esenţială efectuarea înainte de operaţie a unei investigaţii de tip PET-CT şi folosirea unei echipe chirurgicale cu experienţă în această patologie pentru a se putea scoate cât mai puţin ţesut pancreatic normal şi să se evite astfel un diabet secundar.

Conflict of interest: none declared Financial support: none declared

10. Worth C, Yau D, Salomon Estebanez M, O'Shea E, Cosgrove K, Dunne M, Banerjee I. Complexities in the medical management of hypoglycaemia due to congenital hyperinsulinism. Clinical Endocrinology 2020;92(5):387-395.

11. Maiorana A, Manganozzi L, Barbetti F, Bernabei S, Gallo G, Cusmai $\mathrm{R}$, Caviglia S, Dionisi-Vici C. Ketogenic diet in a patient with congenital hyperinsulinism: A novel approach to prevent brain damage. Orphanet Journal of Rare Diseases 2015;10(1):120.

12. Barthlen W, Mohnike W, Mohnike K. Techniques in pediatric surgery: Congenital hyperinsulinism. Horm Res Paediatr. 2011;75(4):304-10.

13. Adzick NS, De Leon DD, States LJ, Lord K, Bhatti TR, Becker SA, Stanley CA. Surgical treatment of congenital hyperinsulinism: Results from 500 pancreatectomies in neonates and children. J Pediatr Surg. 2019;54(1):27-32.

14. Beltrand J, Caquard M, Arnoux JB, Laborde K, Velho G, Verkarre V, Rahier J, Brunelle F, Nihoul-Fékété C, Saudubray JM, Robert JJ, de Lonlay P. Glucose metabolism in 105 children and adolescents after pancreatectomy for congenital hyperinsulinism. Diabetes Care. 2012; 35(2):198-203.

15. Arya VB, Senniappan S, Demirbilek H, Alam S, Flanagan SE, Ellard $\mathrm{S}$, Hussain K. Pancreatic endocrine and exocrine function in children following near-total pancreatectomy for diffuse congenital hyperinsulinism. PLoS One. 2014;9(5):e98054.

16. Calabria AC, Li C, Gallagher PR, Stanley CA, De León DD. GLP-1 receptor antagonist exendin-(9-39) elevates fasting blood glucose levels in congenital hyperinsulinism owing to inactivating mutations in the ATP-sensitive K+ channel. Diabetes. 2012;61(10):2585-91.

17. McMahon AW, Wharton GT, Thornton P, De Leon DD. Octreotide use and safety in infants with hyperinsulinism. Pharmacoepidemiol Drug Saf. 2017;26(1):26-31. 